\title{
KOLABORASI MASYARAKAT EKONOMI, POLITIK, DAN SIPIL DALAM PENGEMBANGAN PARIWISATA BAHARI UNTUK PENGENTASAN KEMISKINAN MASYARAKAT PESISIR DI BALI
}

\author{
I Wayan Mudana \\ Universitas Pendidikan Ganesha \\ Mudanawayan935@yahoo.co.id
}

\begin{abstract}
Abstrak
Tujuan penelitian ini meliputi: 1. Mendeskrepsikan model pemberdayaanmasyarakat pesisir berbasis sosial budaya yang dikembangkan di kawasan pesisir Bali. 2.Mendeskrepsikan bentuk implementasi penguatan modal komunitas yang dikembangkan di kawasan pesisir Bali. 3.Mendeskrepsikan bentuk pengembangan pengawasan keberlanjutan wisata bahari di kawasan pesisir Bali. 4.Mendeskrepsikan model promosi wisata bahari yang dikembangkan di kawasan pesisir Bali. Pendekatan yang digunakan dalam penelitian ini adalah pendekatan kulaitatif yang bersifat etnografis kritis, sehunbungan dengan hal itu maka informan penelitian ini menggunakan purposive smowball, pengumpulan data dengan observasi, wawancara mendalam, studi pustaka, dan diskusi. Analisis data dilakukan secara kualitatif. Berpijak dari hal itu telah diahsilkan sebuah model pembeerdayaan masyarakat pesisir berbasis sosial budaya. Adapun bentuk penguatan modal komunitas yang dilakukan melalui proses sosialisasi, pendampingan dan pemberian bantuan modal finansial. Dalam menjaga keberlanjutan waisata bahari masyarakat mengembangkan pengawasan yang melibatkan masyarakat setempat, lembaga swadaya masyarakat, dan kelembagaan formal. Model promosi wisata bahari yang dikembangkan selama meliputi promosi melalui penyebaran brosur paket wisata bahari, promosi wisata bahari berbasis teknologi informasi, dan melalui kegiatan-kegiatan festival wisata bahari. Pengembangan wisata bahari di kawasan peisisr merupakan ruang hidup yang telah mempu meningkatkan kesejahteraan beberapa anggota masyarakat setempat
\end{abstract}

Kata Kunci : Kolaborasi, PariwisataBahari,KemiskinanMasyarakatPesisir 
While the aims of this study cover; 1. To describe the capacity model of beach community tha have socio-culture that develop in Bali beach area. 2. To describe the forms of strengthening implementation to capital"s community that is developed in Bali beach area. 3. To describe the forms of developing the supervision continuously to the maritime tour in Bali beach area. 4. To describe promotion model maritime tour that is developed in Bali beach area. The approach is used in this study qualitative method with critical ethnography. Acording to the problem, so the informan in this study is used snowball purposive, while the collection of data by observation, great intr intreviuw, litrature study and discussion.Base on the problem. Use snowball purposive, while the collection of data by observation, great interview, litrture study and disccution. Data analysis is done by qualitative method. Base on that problem, there is a trick model of beach community with socio-culturer bases.The shape of capital strngthening that is carried out through socialization process, assistance, and giving help to financial capital. In watching over the maritime tour, the lpcal public develop the supervision to involve the local community, social league and olso formal league. Promotion model of maritime tour, that is developed involve promotion through the brochure, distributing the brochure of maritime tour package, promotion of beach tour with bases of information technology through activities of maritime festival. The development of maritime tour at beach area, symbolizing the life spiece tha could be able to increace the prosusperity to the members of local community.

Key words: Colaboration, Maritime Tour, Poverty of Beach Community 


\section{PENDAHULUAN}

Sektor pariwisata telah lama menjadi primadona penghasil devisa bagi masyarakat Bali. Sumbangan sektor pariwisata terhadap pendapatan daerah Bali dari tahun ke tahun terus meningkat bahkan mengungguli sektor-sektor lainnya. Kenyataan itu seyogyanya juga dirasakan oleh masyarakat sekitar kawasan wisata/ daerah tujuan wisata. Namun, kenyataannya tidak jarang masyarakat sekitar kawasan wisata lebih banyak menonton, bahkan sering menjadi korban pengembangan pariwisata, seperti penggusuran, pengesampingan, pengimpitan pada masyarakat yang ada di sekitar kawasan wisata/ daerah tujuan wisata. Hal ini menyebabkan ketidak adilan dan kemiskinan terus berkembang pada kawasan tersebut (Mudana, 1998; 2012). Terjadinya hal itu disebabkan oleh kurang mampunya masyarakat sekitar/masyarakat sipil bernegoisasi/berkolaborasi dan mempermainkan modal yang dimiliki.Hal seperti itu tentu akan semakin meningkat dengan berkembangnya ideologi ekonomi koboisme (Korten,1993:65) sebagai pencerminan dari keberadaan ekonomi libido atau masyarakat yang terectasy dalam payung agama pasar (Ibrahim,1997; Piliang, 1997; 1998; 1999; 2003;2003; Baudrilland, 2000; Sugiono, 1999; Atmadja, 2006; Atmadja, 2008). Karena ideologi semacam ini berkontribusi bagi berkembangnya kekerasan dan kerusakan lingkungan sekitar ( Atmadja, 2006; Atmadja, 2008: Susilo, 2003:25). Ideologi ekonomi koboismeyang kapitalistik tidak saja menimbulkan kemiskinan pada masyarakat sekitar tetapi juga telah menimbulkan kerusakan lingkungan pesisir dan ekosistemnya (Bali Post, Senin, 27 Juni 2005, Bali Post, Selasa 26 Februari 2008). Kerusakan lingkungan pesisir mengakibatkan semakin terhimpitnya kehidupan masyarakat pesisir.

Terjadinya kekerasan dan pengesampingan terhadap masyarakat kecil dan lingkungan sebagai konskwensi dari paradigma pembangunan yang bersifat modernis dan arogansi pelaksanaan pembangunan yang cenderung berpihak terhadap pemilik modal, serta kurang bersedia belajar dari masyarakat kecil/tradisional (Chambers,1988; Budiman, 1996; Gautama dan Titan, 1999; Shiva, 1997; Sugiono, 1999). Model pembangunan semacam itulah yang telah mengakibatkan terjadinya bias pembangunan (Shiva,1997) atau hegemoni (Sugiono,1999), atau merupakan suatu konsekuwensi logis dari pembangunan dengan pendekatan mekanistis - reduksionistis sebagaimana dikatakan oleh Keraf ( 
2002). Pembangunan semacam itu mengakibatkan modal sosialbudaya dalam bentuk kearifan lokal terabaikan dan tenggelam dalam iruk pikuk hawa nafsu kekuasaan kapitalistik. Padahal kajian-kajian terhadap kearifan lokal dan modal sosial sebagaimana dilakukan oleh Dove (1985), Colletta (1987), Fukuyama (2005), Badaruddin (2005), Atmadja (2006), Hasbullah (2006), dll. menunjukkan akan kebermaknaan modal sosialbudaya dengan berbagai kearifan lokalnya dalam mengatasi berbagai permasalahanpembangunan, termasuk dalam menangani masalah kemiskinan.

Fenomena
merupakan salah satu bentuk dari
kekerasan dan dominasi manusia
terhadap manusia lainnya. Dalam
pencermatan fenomena tersebut
diperlukan pendekatan lintas bidang
ilmu atau paling tidak dengan
menselingkuhkan berbagai teori sosial
kritis (Mariyah, 2006; Kleden, 2006;
Atmdja, 2006).

Berpijak dari hal tersebut di atas maka akan diupayakan untuk mengkaji

tentangKolaborasiMasyarakatEkonomi

Politik,danSipidalamPengembanganPa riwisataBahariUntukPengentasanKemi skinanMasyarakatPesisir di Bali”. Pentingnya pengkajian ini terkait dengan potensi yang dimiliki masyarakat pesisir di Bali dalam mengembangkan wisata bahari. Pengembangan wisata bahari merupakan salah satu program zonasi pemanfaatan kawasan pesisir di Bali. Hal itu artinya masyarakat politik memiliki komitmen untuk mengembangkan wisata bahari di kawasan pesisir Bali. Dalam mewujudkan komitmen tersebut diperlukan kerjasama/kolaborasi tidak hanya dengan masyarakat ekonomi/ pengusaha tetapi juga dengan masyarakat setempat/ masyarakat sipil (Mudana, 2012). Melalui kolaborasi dengan berbagai komponen masyarakat dalam pengembangan wisata bahari tidak saja dapat mewujudkan wisata bahari yang kredibel dan kompetitif tetapi juga dapat meningkatkan kesejahteraan masyarakat sekitar atau mengentaskan kemiskinan masyarakat pesisir. Model pembangunan semacam ini merupakan suatu inflikasi dari pembangunan yang berkeadilan, berkelanjutan, melestarikan dan mensejahterakan. Wacana semacam ini sejalan dengan paradigma ilmu sosial emansipatoris yang dilandasi oleh kesadaran kritis untuk transformasi sosial (Fakih, 2003: 34)

Berpijak latar belakang
masalah tersebut di atas dapat
dirumuskan permasalahan penelitian
ini sebagai berikut:


Adapun permasalahan yang dikaji yang dikaji meliputi:

1. Bagaimana

model pemberdayaan masyarakat pesisir berbasis sosial budaya yang dikembangkan di kawasan pesisir Bali?

2. Bagaimana bentuk implementasi penguatan modal komunitas yang dikembangkan di kawasan pesisir Bali?

\section{PEMBAHASAN}

Pemberdayaan
pesisir dalam pengembarakat penguatan daya dukung wisata bahari perlu adanya pemikiran kritis baik dalam kaitan pemberdayaan masyarakat maupun dalam kaitannya dengan pengembangan pariwisata, khusunya pariwisata bahari jangan sampai menimbulkan kesenjangan, kerusakan lingkungan dan sosiokultural. Untuk itu model pemberdayaan masyarakat dan pengembangan pariwisata yang dikembangkan harus benar-benar dilandasi dengan gagasan kearifan lokal Ideology Nyegara Gunung, Tri Hita Karan dan regulasi yang berkeadilan dan mensejahterakan. Dalam rangka itu juga perlu diupayakan pemberdayaan masyarakat lokal sehingga mereka mampu dalam mengambangkan kolaborasi dengan kelompok masyarakat lainnya yang dapat membantu untuk pengembangan pariwisata bahatri yang berkeadilan dan mensejahterakan.Pengembangan pariwisata bahari yang seperti tentu sejalan dengan konsepsi pembangunan berkelanjutan.Cita-cita dan agenda utama pembangunan berkelanjutan tidak lain adalah upaya untuk mensinkronkan, mengintegrasikan, dan memberi bobot yang sama bagi tiga aspek utama pembangunan, yaitu aspek ekonomi, aspek sosial-budaya, dan aspek lingkungan hidup. Untuk itu ada tiga prinsip utama pembangunan berkelanjutan yang harus diperhatikan dan dioperasionalkan sebagai sebuah politik pembangunan, yaitu: prinsip demokrasi, prinsip keadilan, dan prinsip keberlanjutan. Hanya dengan perubahan pendekatan politik pembangunan seperti itu bisa dijamin bahwa cita-cita dan agenda pembangunan berkelanjutan bisa dicapai. Pengalaman menunjukkan bahwa hasil akhir memang membutuhkan proses panjang. Akan tetapi proses demokratis, berkeadilan, dan berkelanjutan harus dimulai dari sekarang. Untuk itu, dibutuhkan kemitraan dalam semangat saling memahami dan saling percaya yang positif-konstruktif di antara berbagai stakeholders demi menjamin lingkungan hidup menjadi bagian integral dari keseluruhan proses pembangunan. Dalam hal inilah diperlukan adanya suatu sinergi positif antara tiga kekuatan utma, yaitu negara 
dengan kekuatan politik, sektor swasta dengan kekuatan ekonomi, dan masyarakat warga dengan kekuatan moral. Melalui kerjasama positif dan produktif dalam semangat saling mengontrol dan mengimbangi untuk memungkinkan proses dan tujuan pembangunan dapat terwujudkan (Keraf,2005:182).

Pembangunn berkelanjutan senantiasa mengendaki peningkatan kualitas hidup manusia, dan selalu berorientasi jangka panjang dengan prinsip-prinsip keberlanjutan hidup manusia dan lingkungannya di masa sekarang dan akan datang. Di dalam konsep ini manusia dengan segala aspek hidupnya bersama dengan komponen lingkungan alam dan lingkungan binaan/buatan dilihat sebagai suatu kesatuan dalam apa yang dinamakan lingkungan hidup. Lingkungan hidup adalah kesatuan ruang dengan semua benda, daya, keadaan, makhluk hidup, termasuk manusia dan perilakunya, yang mempengaruhi kelangsungan perikehidupan dan kesejahtraan manusia serta makhluk lain.Lingkungan hidup itu juga merupakan sebuah sistem yang utuh, kolektivitas dari serangkaian subsistem yang saling berhubungan, saling tergantung dan fungsional satu sama lain, sehingga membentuk satu kesatuan ekosistem yang utuh (Purba,2005:13). Dalam hal ini terjadi interaksi antara manusia dengan berbagai komponen ekosistem. Interaksi manusia dengan berbagai komponen ekosistem tampak dari berbagaitindakan sosial manusia.

Untuk mewujudkan hal itu dip[andang perlu melakukan pemberdayaan pada seluruh komponen masyarakat di daerah pengembangan wisata bahari. Proses pemberdayaan dalam konteks teori kritis sejalan dengan konsepsi yang dikembangkan dalam teori konstruktivisme. Konsep konstruksionisme diperkenalkan oleh sosiolog interpretatif, Peter L.Berger dan Thomas Luckman. Mereka banyak menulis karya dan menghasilkan tesis mengenai konstruksi sosial atas realitas. Realitas sosial terbentuk secara sosial dan realitas sosial baru memiliki makna ketika realitas sosial tersebut dikonstruksi dan dimaknai secara subjektif oleh orang lain sehingga memantapkan realitas tersebut secara objektif. Oleh karena itu setiap orang berpeluang melakukan konstruksi yang berbeda-beda atas suatu realitas. Pemahaman semacam ini akan menimbulkan realitas sosial yang bersifat plural. Setiap konstruksi yang dibuat itu dilengkapi dengan legitimasi-legitimasi tertentu dengan sumber kebenaran tertentu pula, sehingga kontruksinya menjadi kuat dan dipercaya sebagai suatu kebenaran. Teori konstruksi sosial 
menyatakan bahwa realitas kehidupan sehari-hari memiliki dimensi subjektif dan objektif. Tesis utamanya adalah manusia dan masyarakat adalah produk yang dialektis, dinamis, dan plural secara terus menerus (Berger dan Luckman, 1990, 66-248; Eriyanto, 2008, 104-118).

Proses dialektis tersebut mempunyai tiga momen. Yang pertama, ekternalisasi, yaitu usaha pencurahan atau ekspresi diri manusia ke dalam dunia, baik dalam kegiatan mental maupun fisik. Yang kedua, obyektivasi, yaitu hasil yang telah dicapai, baik mental maupun fisik dari kegiatan ekstrernalisasi manusia tersebut. Hal itu menghasilkan realitas objektif yang bisa jadi akan menghadapi si penghasil itu sendiri. Realitas objektif tersebut menjadi kenyataan emperis yang bisa dialami oleh setiap orang. Yang ketiga, internalisasi, proses ini lebih merupakan penyerapan kembali dunia objektif ke dalam kesadaran sedemikian rupa sehingga subjektivitas individu dipengaruhi oleh struktur dunia sosial (Berger dan Luckman, 1990: 185-233; Rosyadi, 2008: 5-11; Eriyanto, 2008: 13-37; Riyanto,2009: 112).

Konstruktivisme merupakan
kerja kognitif individu untuk
menafsirkan dunia realitas yang ada
dalam setiap relasi sosial antara individu dengan lingkungannya. Melalui hal itu, individu membangun pengetahuan atas realitas yang dilihatnya berdasarkan struktur pengetahuan yang telah ada sebelumnya. Hal ini, oleh Berger dan Luckman (1990: 232) disebut dengan kontruksi sosial. Dalam kenyataannya, realitas sosial tidak berdiri sendiri, tanpa kehadiran seseorang, baik di dalam maupun di luar realitas tersebut. Realitas sosial memiliki makna ketika realitas tersebut dikonstruksi dan dimaknai secara subyektif oleh oarang lain. Sehubungan dengan hal itulah, dikatakan bahwa kehidupan sehari-hari menyimpan dan menyediakan kenyataan, sekaligus membimbing perilaku dalam kehidupan sehari-hari. Kehidupan sehari-hari menampilkan realitas objektif yang ditafsirkan oleh individu, atau memiliki makna-makna subyektif. Di sisi yang lain, kehidupan sehari-hari merupakan dunia yang berasal dari pikiran-pikiran dan tindakan-tindakan individu yang dipelihara sebagai sesuatu yang nyata oleh pikiran dan tindakan itu, yang lebih lanjut membentuk dunia akal sehat intersubyektif yang dimiliki bersama (Bungin, 2007: 192).

Dalam perspektif Bourdieu (Ritzer dan Goodman, 2005: 518-523), sebagaimana dikemukakan dalam teori konstruksi interpretatif atau kontruksi strukturalis, konstruksi sosial sangat 
penting artinya dalam dinamika kehidupan individu dan masyarakat karena, melalui proses konstruksi sosial, aktor merasakan, memikirkan, dan membangun struktur serta kemudian bertindak berdasarkan struktur yang dibangunnnya. Hal ini terkait dengan pemikirannya tentang hubungan dialektika antara struktur objektif dan fenomena subjektif, dialektika antara struktur dan keagenan, dan dialektika antara struktur dan cara orang membangun realitas sosial, serta dialektika antara habitus dan lingkungan. Habitus ada di dalam pikiran aktor, lingkungan ada di luar pikiran aktor.

Di dalam dilektika ini terjadi permainan sosial. Permainan sosial merupakan mekanisme reproduksi hubungan-hubungan dominasi antarindividu dan kelompokkelompok. Mekanisme yang dibangun adalah upaya menetapkan budaya penguasa dalam rangka membedakan diri dari apa yang dilakukan oleh orang kebanyakan. Hal ini merupakan suatu strategi untuk mempertahankan dominasi, bahkan dijadikan sarana untuk mengkumulasikan jenis-jenis modal (Haryatmoko, 2003: 4-23). Akumulasi modal memang sangat penting bagi setiap orang karena modal memainkan peranan menentukan untuk mengendalikan orang lain.
Dengan demikian, dialektika yang dibangun oleh individu dan berbagai kelompok sosial adalah dalam rangka mempertahankan struktur dominan. Dalam konteks pembangunan yang berkelanjutan, modal sosial dan modal manusia senantiasa harus naik (Nugroho, 1997: 7).Masyarakat sebagai relaitas objektif menyiratkan proses-proses internalisasi/pelembagaan yang diawali dengan ekternalisasi yang dilakukan berulang-ulang sehingga terlihat polanya dan dipahami bersama yang kemudian menghasilkan pembiasaan/habitus (Jenkins, 2004: 106-124; Ritzer, dan Goodman, 2005: 518-523). Dalam rangka ini, agen sosialisasi, baik individu, kelembagaan, maupun media massa memegang peranan penting.

Habitus adalah struktur kognitif yang ada di antara individu dan realitas sosial. Individu menggunakan habitus dalam berurusan dengan realitas sosial. Habitus merupakan struktur subjektif yang terbentuk dari pengalaman individu berhubungan dengan individu lain dalam jaringan struktur objektif yang ada dalam ruang sosial. Habitus adalah produk sejarah yang terbentuk setelah manusia lahir dan berinteraksi dengan masyarakat dalam ruang dan waktu. Habitus merupakan hasil pembelajaran lewat pengasuhan, aktivitas bermain, 
dan pendidikan masyarakat dalam arti luas, termasuk media massa. Habitusmendasari ranah yang merupakan jaringan relasi antarposisi objektif dalam suatu tatanan sosial.

Ranah mengisi ruang sosial/arena. Istilah ruang sosial/arena mengacu pada keseluruhan konsepsi tentang dunia sosial. Ruang sosial individu dikaitkan melalui waktu dengan serangkaian ranah tempat terjadinya perebutan berbagai bentuk modal (modal ekonomi, budaya, simbolik dan sosial) (Takwin, 2005: xix-xxv; Jenkins, 2004: 106-124). Arena adalah suatu sistem posisi sosial yang terstruktur yang dikuasai oleh individu atau institusi tertentu. Hal itu juga menyiratkan suatu sistem kekuatan yang ada di antara posisi tersebut, suatu arena yang distrukturkan secara internal dalam konteks relasi kekuasaan.

Dengan meminjam teori Booudieu, tentu hal itu akan diawali dengan proses Habitualisasi, atau menurut Gramsci dengan hegemoni. Habitualisasi yang telah berlangsung memunculkan pengendapan dan tradisi yang kemudian diwariskan kepada generasi berikutnya melalui bahasa, agen, dan media massa. Melalui hal inilah bahasa menjadi wacana yang mendominasi arena, ia menjadi norma yang diterima kebenarannya, bahkan makna wacana yang lain ditentukan oleh wacana dominan ini, yang disebut doxa (Rusdiartini, 2003:31; Fashri, 2007:126).

Sehubungan dengan hal itulah, dalam setiap arena sosial akan terjadi pertarungan wacana. Doxa adalah kepercayaan dan nilai-nilai tak sadar, berakar mendalam, mendasar, yang dipelajari, yang diangggap sebagai universal-universal yang terbukti dengan sendirinya, yang menginformasikan tindakan-tindakan dan pikiran-pikiran seorang agen dalam ranah tertentu (Rusdiartini, 2003: 31; Fashri,2007:126). Dalam kaitan inilah masyarakat sebagai realitas objektif juga menyiratkan keterlibatan legitimasi. Legitimasi merupakan objektivasi makna tingkat kedua/ makna kontatif. Dalam konteks semiotika, dikenal adanya makna denotatif dan konotatif. Makna konotatif adalah makna tingkat kedua dalam konteks semiotika (Hoed, 2008: 10; Tinarbuko, 2008: 19; Audifax, 2007: 33-37; Sobur, 2006: 262-266).

Bali merupakan daerah yang memiliki keaneka ragaman potensi.Hal inilah yang menjadikan daerah Bali sebagai tujuan wisata yang sangat menarik (Covarrubias, 2013). Keberadaan daerah Bali sebagai daerah tujuan wisata dalam perspektif rwa Binneda, hal itu tentu saja dapat berdampak positif dan negatif bagi 
dinamika sosial, kultural, dan ekonomi masyarakat Bali.Fenomena itu menarik berbagai pihak untuk mengkajinya. Hal ini dapat disimak dari adanya kajian yang dilakukan oleh Atmadja (1993) tentang Pengelolaan Hutan Wisata Kera Sangeh oleh Desa Adat Sangeh, Bali. Kajian ini mengungkapkan kontribusi Desa Adat dan kepercayaan masyarakat dalam melestarian Hutan Sangeh. Mudana (1997) mengkaji tentang Terhimpit di Balik Lipatan Dolar (Kajian Antropologi Terhadap Kehidupan Nelayan pada Kawasan Pemukiman Wisata di Pantai Bali Utara). Kajian ini mengungkapkan telah terjadi keterhimpitan masyarakat lokal di kawasan pemukiman wisata.Pujaastawa, dkk (2005) mengkaji tentang Pariwisata Terpadu Alternatif Model Pengembangan Pariwisata Bali Tengah.Melalui kajian ini terungkap arti penting pengembangan pariwisata terpadu dalam mensinergiskan dan memaksimalkan pemanfaatan dan kebermaknaan pengembangan pariwisata.Hajib (2006) mengkaji tentang Aplikasi Teori Postmodernisme terhadap Aspek Pemberdayaan Masyarakat (Community Empowerment) pada Daerah Tujuan Wisata.Kajian ini mengungkapkan bahwa dengan penerapan teori postmodernisme dalam pemberdayaan masyarakat di bidang pariwisata dapat meningkatkan kualitas aktivitas pariwisata yang berkelanjutan.Anom, dkk. (2010) melalui kajiannya tentang Pariwisata Berkelanjutan dalam Pusaran Krisis Global, mengungkapkan pentingnya pemberdayaan dalam pengembangan pariwisata berkelanjutan. Pitana (2011) mengkaji tentang Pemberdayaan dan Hiperdemokrasi dalam Pembangunan Pariwisata.Dalam kajian ini terungkap arti penting pemberdayaan masyarakat dalam pemanfaatan sumber daya lokal untuk meningkatkan kesejahteraan masyarakat setempat.

Setelah dicermati secara mendalam kajian-kajian tersebut menginpirasi dalam pengkajian tentang pemberdayaan masyarakat Pesisir di Bali. Dan juga harus diakui bahwa kajian - kajian tersebut berkontribusi dalam pengembangan wawasan dalam pengembangan kajian pemberdayaan masyarakat dalam kaitannya dengan keberadaan daerah Bali sebagai daerah tujuan wisata.Sehubungan dengan hal itu kajian tentang hal itu penting dilakukan. Petingnya kajian tentang pemberdayaan masyarakat juga terkait dengan keberadaan Desa-Desa Pesisir sebagai daerah tujuan wisata yang sedang berupaya menata pengembangan pariwisata berkelanjutan, baik secara ekonomi, sosiokultural maupun lingkungan. Pengembangan pariwisata 
berkelanjutan sangat tergantung pada proses pemberdayaan masyarakat.

Dalam mengkaji tentang hal tersebut digunakan teori pemberdayaan masyarakat dan teori pembangunan berkelanjutan. Adapun teori pemberdayaan masyarakat yang digunakan diataranya teori pemberdayaan masyarakat berbasis komunitas yang bertumpu pada keberadaan pranata sosial budaya dan psikokultural masyarakat (Bagong Suyanto, 2005;H.Moh Ali Aziz, 2005; H.Nur Syam, 2005). Dalam proses pemberdayaan Jack Rothman sebagaimana dikutip oleh Edi Suharto (2005) mengemukakan tiga model pengembangan masyarakat yaitu: pengembangan masyarakat lokal, perencanaan sosial dan aksi sosial.Harry Hikmat menyatakan ada tiga strategi utama pemberdayaan yaitu: tradisional, aksi langsung, dan transformasi $(2010,19)$.Ketiga strategi tersebut cendrung dilakukan secara terpadu, melalui tiga aras pemberdayaan yaitu aras mikro, mezzo dan makro (Suharto, 2005, 66-67). Berbicara tentang proses pemberdayaan masyarakat tentujuga terkait dengan teori konstruksi sosial interpretative sebagaimana dikemukakan oleh Peter L. Berger dan Thomas Luckman, yang menyatakan bahwa realitas sosial terbentuk secara sosial dan baru memiliki makna setelah dikonstruksi dan dimaknai secara subjektif (1990, 66; Eriyanto, 2008, 204-118; Riyanto, 2009). Teori konstruksisosial sangat penting artinya dalam dinamika kehidupan individu dan masyarakat, karena melalui proses konstruksi sosial aktor merasakan, memikirkan, dan membangun struktur serta kemudian bertindak berdasarkan struktur yang dibangunnya (Ritzer dan Goodman, 2005: 518-523) ). Di samping teori pemberdayaan kajian ini juga memanfatkan teori pembangunan berkelanjutan terkait dengan pengembangan pariwisata berkelanjutan.Teori pembangunan berkelanjutan kehadirannya terkait dengan adanya ketimpangan pembangunan sebagai konskwensi dari adanya dominan paradigma pembangunan ekonomi yang kapitalistik. Dengan kata lainteori pembangunan berkelanjutan pada dasarnya merupakan suatu alternative untuk mengatasi terjadinya ketimpangan pembangunan.Karena itu teori pembangunan berkelanjutan dipandang sebagai keterpaduan dari paradigmaeco-developmentalisme, eco humanism dan eco environmentalism. Sehubungan dengan hal tersebut pembangunan berkelanjutan pada dasarnya menganut tiga prinsip utama, yaitu: (1) kelangsungan ekologi; (2) kelangsungan sosial budaya; dan (3) kelangsungan ekonomi, baik untuk generasi sekarang maupun untuk generasi yang akan dating (Anom, 
2010: 5). Konsep pembangunan berkelanjutan semacam itu kemudian diadopsi dalam mengembangkan konsep pembangunan pariwisata berkelanjutan.Ketiga prinsip utama pembangunan berkelanjutan juga harus tampak dalam pembanguan pariwisata berkelanjutan.Dengan demikian pembangunan pariwisata berkelanjutan tidak hanya menekankan adanya keberlanjutan sumber daya alam, dan ekonomi, tetapi juga keberlanjutan sumber daya sosiokultural (Ariana, 2010:179).Dalam pembangunan pariwisata berkelanjutan ketiga hal itu bersinergi sehingga tiga elemen pariwisata, yaitu masyarakat setempat, wisatawan, dan sumber daya, dapat berjalan secara simbang dan harmonis serta terjaga kualitasnya (Ariana, 2010: 180). Berpijak dari hal itu diperlukan adanya proses kontruksi sosial dan kontrols sosial. Kontrol sosial dalam perspektif teori kritis dapat diadopsi dari pemikiran Foucault tentang Discipline dan Punish (Foucault, 1997:22-31; Haryatmoko, 2002: 146; Ritzer, 2003: 93-130).

Dalam pengkajian tentang upaya pemberdayaan masyarakat yang telah dilakukan pada masyarakat pesisir diperlukan pemahaman tentang konsep pemberdayaan masyarakat. Konsep pemberdayaan masyarakat meerupakan salah satu konsep utama dalam Sosiologi-Antropologi
Pembangunan. Secara konseptual, pemberdayaan atau pemberkuasaan (empowerment), berasal dari kata "power" (kekuasaan atau keberdayan). Karenanya, ide utama pemberdayaan bersentuhan dengan konsep mengenai kekuasaan. Kekuasaan seringkali dikaitkan dengan kemampuan kita untuk membuat orang lain melakukan apa yang kita inginkan, terlepas dari keinginan dan minat mereka. Pandangan semacam itu merupakan pandangan yang sempit terhadap kekuasaan.Karena kekuasaan senantiasa hadir dalam konteks relasi sosial antar manusia, sehingga kekuasaan dapat berubah-ubah sesuai dengan seting sosialnya. Dengan pemahaman kekuasaan seperti ini, memungkinkan bagi terjadinya proses pemberdayaan. Pemberdayaan memiliki kebermaknaan yang sangat berarti terutama pada kelompok renta dan lemah sehingga mereka memiliki kekuatan atau kemampuan dalam memenuhi kebutuhan dasar sehingga mampu menjangkau sumber-sumber produktif yang memungkinkannya meningkatkan pendapatan. Serta memiliki kemampuan dalam berpartisipasi dalam proses pembangunan dan pengambilan keputusan-keputusan dalam mengatasi berbagai masalah yang diadapinya. Secara teoritis dalam pemberdayaan masyarakat ada tiga model yang umum dilakukan, yaitu: (1) model 
pengembangan masyarakat lokal; (2) model perencanaan sosial; dan (3) model aksi social (Suharto, 2005: 42). Pada masyarakat Pesisir tampaknya ke tiga model pemberdayaan tersebut diterapkan, namun yang paling dominan adalah model pemberdayaan masyarakat lokal. Hal ini dapat dilihat dari keterlibatan dan partisipasi masyarakat lokal dalam proses pemberdayaan guna terwujudnya kemandirian, integrasi masyarakat dengan lingkungan sosiokultural dan alam sekitarnya melalui peningkatan kemampuannya. Hal itu dilakukan baik kepada seluruh masyarakat maupun pada beberapa bagian masyarakat melalui kerjasama antara kelembagaan masyarakat Desa Pakraman, Desa Dinas atau kelompokkelompok fungsional yang ada pada masyarakat dengan pihak ketiga. Berpijak dari hal itu strategi pemberdayaan yang dikembangkan pada masyarakat pesisir pada umumnya cendrung menggunakan strategi aras mezzo, namun dalam hal hal tertentu juga digunakan strategi mikro dan makro. Pengembangan strategi ini terlihat dari upaya pemberdayaan dilakukan terhadap sekelompok anggota masyarakat yang tergabung dalam satuan organisasi tertentu.Pemberdayaan semacam ini menggunakan kelompok sebagai media intervensi. Pendidikan dan pelatihan , dinamika kelompok umumnya pada masyarakat pesisir digunakan sebagai strategi dalam eningkatkan kesadaran, penghetahuan, keterampilan, dan sikap-sikap masyarakat agar memiliki kemampuan memecahkan masalah yang dihadapinya.

Fenomena ini dapat disimak dari inisiatif dan keterlibatan aktif masyarakat desa dalam menangggapi pandangan pengusaha untuk mengembangkan kawasan pesisir sebagai desa tujuan wisata. Tanggapan terhadap hal itu dilakukan dalam suatu forum rembug atau sangkepan desa. Forum tersebut merupakan forum yang terbuka bagi dialog antar anggota masyarakat dalam menetapkan suatu keputusan. Dalam forum tersebut hadir tokoh-tokoh masyarakat dan anggota masyarakat pada umumnya.Melalui rembug desa semacam itu disepakati untuk mengembangkan Desa-desa di kawasan pesisir sebagai daerah tujuan wisata. Sebagai suatu ilustrasi dalam mengembangkan kawasan pesisir, misalnya Desa Pemuteran sebagai desa tujuan wisata, disepakati juga bahwa setiap pengembang fasilitas wisata harus berpegang pada prinsip $60 \%$ lahan digunakan peruntukannya untuk ruang terbuka hijau dan $40 \%$ untuk bangunan fasilitas wisata; setiap pengembang pariwisata di Desa Pemuteran dalam perekrutan tenaga kerja harus mengutamakan tenaga kerja lokal; setiap pengembang 
pariwisata ikut berkontribusi terhadap pembangunan masyarakat desa; dan adanya forum dialog secara berkelanjutan antara tokoh masyarakat Desa Pakraman, Desa Dinas,dengan pengusaha pariwisata setiap akhir bulan.

Partisipasi aktif dari masyarakat Desa Pemuteran dalam pengembangan Desa Pemuteran sebagai daerah tujuan wisata juga dapat dilihat dari inisiatif masyarakat lokal dalam mengembangkan dan memberdayakan pecalang segara.Organisasi ini merupakan hasil kreativitas masyarakat dalam mengoptimalkan keberfungsian dari oraganisasi pecalang yang sudah ada di bawah Desa Pakraman.Hal ini sejalan dengan adanya proses transformasi desa pakraman sebagaimana diungkapkan oleh Pitana (1998). Anggota dari organisasi ini berasal dari wakil-wakil dadia atau kelompok kekerabatan berdasarkan kesatuan cikal bakal/ leluhur.Keberfungsian dari oranisasi ini telah mengantarkan Desa Pemuteran sebagai Desa Model dalam pengembangan pariwisata yang mendukung pelestarian terumbu karang dengan melibatkan partisipasi aktif dari tiga pilar masyarakat yaitu masyarakat sipil, masyarakat ekponomi/pengusaha dan masyarakat politik/ pemerintah.
Dalam proses pemberdayaan masyarakat lokal memanfaatkan berbagai ruang sosial yang dimiliki masyarakat setempat. Ruang ruang sosial tersebut merupakan suatu arena dalam proses kontruksi sosial. Adapun ruang-ruang sosial yang dimanfaatkan sebagai arena sosial dalam mengkonstruksi atau memberdayakan masyarakat diantaranya adalah paruman desa pakraman atau pertemuan desa pakraman, aktivitas upacara keagamaan, dan pertemuanpertemuan organisasi kemasyarakatan yang ada di desa (Karang Taruna, Teruna Teruni, PKK, Pecalang Segara, Yayasan Anak Pemuteran). Di samping itu juga memanfaatkan kelembagaan pendidikan yang ada di Desa Pemuteran. Dengan dekian berbagai potensi kelembagaan merupakan ruang sosial yang strateis bagi proses pengkonsruksiaan/ pemberdayaan masyarakat baik dalam kaitannya dengan pelestarian lingkungan khususnya pelestarian terumbu karang, pengintegrasian sosial/ keharmonisan hubungan antar anggota masyarakat, penguatan kehidupan ekonomi dan pengembangan pariwisata berkelanjutan. Proses semacam itu tentu saja pelaksaan sangat tergantung dari peran kelembagaan Desa Dinas dan klembagaan Desa Pakraman.

Upaya pemberdayaan masyarakat Desa Pemuteran dalam 
mendukung pengembangan pariwisata yang sustainebelity juga melibatkan pihak ke tiga, seperti Yayasan Karang Lestari yang disponsori oleh I Gst Agung Prana pengusaha pariwisata pemilik Hotel Taman Sari, Yayasan Bio Rock. Yayasan tersebut secara konsisten melakukan pendampingan terhadap masyarakat setempat dalam menjaga kelestarian lingkungan alam pesisir, khususnya dalam melestarikan terumbu karang.Kelestarian terumbu karang di kawasan pesisir pemuteran merupakan daya tarik tersendiri bagi wisatawan. Dengan kata lain pelestarian terumbu karang memiliki keberfungsian dalam mendukung pengembangan pariwisata yang sustainability terhadap lingkungan. Karena pelestarian terumbu karang tidak saja memberikan kontribusi terhadap pengembangan pariwisata, peningkatan kehidupan ekonomi tetapi juga berkontribusi bagi kelestarian lingkungan.Upaya kearah pelestarian terumbu karang tidak saja melibatkan masyarakat lokal tetapi juga masyarakat luar. Hal ini dapat disimak dari adanya upaya melibatkan wisatawan untuk ikut berkontribusi dalam pelestarian terumbu karang melalui sponsor pelestarian terumbu karang, sebagaimana yang diwacanakan dalam reklama sponsor a baby coral.

Reklama tersebut merupakaan ide yang sangat kreatif dari Yayasan
Bio Rock untuk melestarikan terumbu karang melalui bantuan dari pihak ke tiga. Reklama tersebut menggunakan bahasa Inggris.Reklama sebagai suatu teks tentu memiliki makna denotative dan konotatif, serta sarat dengan berbagai kepentingan dan pertarungan ideologi.Penggunaan bahasa Inggris menyiratkan bahwa masyarakat setempat telah berhasil memberdayakan sebagian dari masyarakatnya dalam berbahasa Inggris, kemampuan berbahasa asing merupakan suatu kemampuan penting bagi masyarakat di daerah tujuan wisata. Karena dengan kemampuan berbahasa asing akan memberikan peluang yang lebih besar untuk ikut terlibat dalam aktivitas di daerah tujuan wisata, atau dengan kata lain masyarakat setempat lebih mudah dalam memanfaatkan berbagai peluang di daerah tujuan wisata.

Namun bila dicermati dari perspektif teori strukturasi Giddens dengan oposisi binerynya ( 1985 , 2003, 2005), reklame tersebut menyiratkan adanya pendekotomian antara dua kelompok masyarakat, yaitu masyrakat tradisional dengan masyarakat modern, masyarakat terbelakang dengan masyarakat maju, masyarakat lokal dengan masyarakat internasional/tamu, masyarakat miskin dengan masyarakat kaya, masyarakat yang tidak berdaya dengan masyrakat berdaya. Hal lain yang cukup menarik 
adalah adanya ungkapan :Please Contact: Komang at The Bio-Rock Center or Phone Him: 0812461370: HTTP://WWW.BIOROCK.Ungkapan tersebut tidak saja memiliki makna denotative dalam kaitannya dengan aktivitas komunikasi, tetapi juga merupakan pencitraan sebagai masyarakat yang berdaya, terbuka, maju, modern, dan memiliki kemampuan dalam memanfaatkan masyarakat global dengan isu lingkungannya.Kondisi keberdayaan dari masyarakat Desa Pemuteran juga disiratkan oleh teks dari iklan yang dipajangkan.Dengan meminjam pandangan Roland Barthers bahwa pesan linguistik dari iklam tersebut mengungkapkan harapan kepada masyarakat internasional untuk ikut mendanai keberlanjutan dari proyek pelestarian terumbu karang di Desa Pemuteran.Pemanfaatan teknologi modern seperti internet dan HP dalam perspektif Pilliang menunjukan semakin terbebasnya sekat-sekat dunia sehingga dapat mempersempit jarak dan mempersingkat waktu/mempercepat komunikasi antar kelompok masyarakat di belahan dunia, hal itu menyiratkan dunia telah dilipat ( 1998; Atmadja, 2006). Bila hal ini dikaitkan dengan pemikiran Foucault yang menyatakan bahwa kekuasaan itu menyebar, maka dapat dikatakan bahwa kuasa dalamiklan tersebut telah mempengaruhi dan mengarahkan pihak lain dalam hal ini masyarakat internasional khususnya wisatawan untuk menjadi donator pelestarian terumbu karang. Dalam kuasa masyarakat Desa Pemuteran tentu saja tidak terbebas dari konstruksi berbagai ideologi seperti ideologi, salah satu diantaranya adalah ideologi Tri Hita Karana guna mewujudkan pengembangan pariwisata yang berkeselarasan dengan lingkungan ( Salim, 1983; Sukadana, 1983; Sanderson, 1993).

Praktik kuasa dalam media iklan tersebut tentu saja terkait dengan keberhasilan proses pemberdayaan masyarakat yang diwujudkan dalam bentuk kemampuan membuat iklan dan mempermaikan modal natural, modal sosial, modal sumber daya manusia dan modal intelektual yang dimilikinya, sehingga memperkuat kuasa dalam iklan yang dipajangkannya Badaruddin, 2005). Upaya semacam itu tentu merupakan upaya yang sangat positif bagi pelestarian lingkungan dan sekaligus juga berkontribusi bagi pengebangan pariwisata bahari yang berkearifan lingkungan.Upaya semacam ini juga didukung sepenuhnya oleh pemerintah kabupatemn Buleleng, melalui Dinas Kelautan dan Perikanan kabupaten Buleleng, Dinas Pariwisata. Di samping mendapatkan dukungan dari LSM, Pengusaha Pariwisata, Pemerintah Daerah, program 
pengembangan pariwisata yang sustainebelity terhadap lingkungan juga mendapat dukungan dari lembaga perguruan tinggi, yaitu Universitas Ganesha melalui program P2M Desa Binaan.

Upaya pemberdayaan juga dilakukan oleh Universitas Pemndidikan Ganesha, melalui program desa binaan.Kegiatan pengabdian pada masyarakat Desa Binaan yang dilakukan meliputi pembinaan pelestarian lingkungan, pengembangan kuliner berbasis potensi lokal, pembinaan guru-guru, dan pembinan karang taruna. Kegiatan tersebut dimaksudkan untuk mengembangkan sumberdaya manusia yang memiliki wawasan yang luas baik yang terkait dengan masalah lingkungan, keorganisasian maupun mengenai masalah kuliner yang dapat mendukung pengembangan pariwisata berkelantan.

Upaya pemberdayaan juga dilakukan melalui ruang sosial Yayasan Anak Pemuteran yang disponsori oleh pemilik Hoten Puri Ganesha, yayasan ini menampung anak-anak pemuteran yang kurang mampu untuk membiayai keberlanjutan pendidikannya. Yayasan ini menyediakan beberapa pasilitas pembelajaran seperti ruang computer, ruang perpustakaan, dan ruang pelatihan tabuh dan tari Bali.Anakanak dari yayasan ini diberikan ruang untuk menunjukkan kebolehananya menari dan menabuh di haotel-hotel yang ada di Desa Pemuteran.Upaya yang dilakukan yayasan ini memberikan kontribusi yang berarti bagi pelestarian budaya Bali dan pengembangan pariwisata yang sustainebelity terhadap budaya masyarakat setempat.

Masyarakat memberikan tanggapan positif terhadap model pola pemberdayaan dalam pelestarian lingkungan alam dan sosiokultural yang dilakukan untuk pengembangan pariwisata yang berkelanjutan terhadap lingkungan, sosiokultural masyarakat. Hal ini dapat dilihat dari dukungan masyarakat terhadap berbagai upaya yang dilakukan baik yang bersifat melembaga maupun yang bersifat personal. Sebagaimana nampak dari dukungan kelembagaan Desa Pakraman, Desa Dinas, Pecalang Segara, Yayasan Anak Pemuteran, Yayasan Bairock, dan kelembagaan pendidikan yang ada di Desa Pemuteran. Regulasi yang dikembangkan selama ini berbasis Desa Pakraman yang pengembangan aturannya diambil melalaui pararem desa, mengacu pada awig-awig desa pakraman dan pararem desa dijiwai oleh kearifan sosiokultural . Di masa depan masyarakat desa pemuteran perlu mengmbangkan berbagai peraturan desa yang lebih 
komprehensif dan detail baik sebagai penjabaran lebih lanjut dari aturanm perundangan yang lebih tinggi, maupu sebagai penjabaran lebih lanjut dari awig-awig Desa Pakraman danpararem Desa Pakraman. Tentu saja regulasi yang dikembangkan perlu ditindak lanjuti dalam bentuk pemberdayaan dan pensosialisasian ke pada berbagai komponen masyarakat, sehingga seluruh anggota masyarakat memiliki pemahaman yang baik mengenai aturan yang dikembangkan. Pengembangan model pola pembnerdayaan dalam pelestarian lingkungan alam dan sosiokultural guna pengembangan pariwisata yang berkelanjutan didukung oleh berbagai fenomena sosiokultural masyarakat setempat sepertiideologi nyegara gunung, tri hita karana, menyama beraya, tatwam asi, asah,asih asuh, dan sagilik saguluk sabayan taka, asah, asih, asuh. Fenomena soiokultural semacam itu tentu saja tidak saja memberikan penguatan terhadap model pola pemberdayaan, tetapi juga akan dapat memperkuat keharmonisan dan integrasi masyarakat. Secara sederhana model pola pemberdayaan masyarakat dalam pengembangan pariwisata yang berkelanjutan dapat digambarkan dalam bagan berikut:

\section{Penguatan Modal Komunitas}

Kolaborasi antara masyarakat ekonomi, politik dan sipil dalam penguatan modal komunitas dan pengembangan wisata bahari untuk pengentasan kemiskinan atau yang mensejahterakan dipengaruhi oleh berbagai faktor yang berkontribusi bagi terwujudnya kepentingan bersama maupun kepentingan bagi kelompok masyarakat tertentu. Hal yang harus terus disadari bahwa masing-masing kelompok masyarakat tidak dapat bekerja sendiri-sendiri dalam melaksanakan pembangunan termasuk dalam mengembangkan pariwisata bahari yang mensejahterakan, melaikan harus saling berinteraksi, berdialog, dan bekerjasama. Idealnya ketiga pilar tersebut tumbuh dalam sebuah kekuatan yang saling mengimbangi, saling mengontrol, saling menopang, dan pada akhirnya bersinergi untuk memajukan keadaban. Kondisi ideal semacam itu sering sulit diwujudkan dalam kehidupan masyarakat. Bahkan tidak jarang dalam kondisi masyarakat sipil yang lemah, negara yang otoritarian berkomplot dengan masyarakat ekonomi dalam pengembangan pariwisata bahari melalui mekanisme pasar. Hal mana tentu akan mengakibatkan relasi tiga pilar menjadi timpang ( Wiratmoko, 2005: xxv). Persengkongkolan antara masyarakat politik dan ekonomi dalam 
pengembangan pariwisata bahari semacam itu tidak saja dapat menimbulkan pengesampingan dan kekerasan terhadap masyarakat pesisir tetapi juga dapat menimbulkan kekerasan dan kerusakan terhadap lingkungan.

Dalam setiap komunitas, selalu akan dijumpai keberadaan masyarakat ekonomi, politik dan sipil. Ketiga kelompok masyarakat tersebut mempermainkan berbagai modal yang ada dalam suatu komunitas untuk memenuhi kebutuhan dan kepentingnannya. Modal yang dipermainkan pada berbagai arena sosial mencakup modal ekonomi, modal sumber daya manusia, modal natural, modal politik, bahkan tidak tertutup kemungkinan modal tubuh yang dimilikinya. Dalam setiap permainan, penguasaan modal akan menentukan posisi atau keberadaan dari masing-masing kelompok masyarakat. Di samping itu, menurut Bourdieu, posisi sesesorang atau sekelompok orang juga akan ditentukan oleh "kemelek-hurufan budaya" (cultural literacy), yaitu pengetahuan akan sistem-sistem makna dan kemampuaannya untuk menegoisasikan sistem-sistem itu dalam berbagai konteks budaya (Aryani, 2003). Sehubungan dengan hal itulah dalam setiap permainan, akan terjadi dominasi dan kolaborasi.
Dominasi akan terjadi bila mana penguasaan modal terkonsentrasi pada kelompok masyarakat tertentu. Karena setiap masyarakat pada dasarnya tidak mengendaki terdominasi, setiap kelompok akan berusaha mempertahankan modal yang dimilikinya. Hal inilah yang tidak jarang menjadi peluang bagi terjadinya konflik dalam masyarakat. Untuk menghindari terjadinya konflik antarkelompok masyatrakat, maka setiap masyarakat mengupayaklan penginvestasian modal sosial sebagai suatu alternatif dalam meredam konflik (Atmadja, 2007; Rai, 2006; Mudana, 2010) karena modal sosial pada dasarnya merupakan segala hal yang berkaitan dengan kerja sama dalam masyarakat untuk mencapai kualitas hidup yang lebih baik, dan ditopang oleh nilai-nilai dan norma yang menjadi unsur-unsur utamanya (Fukuyama, 2005: 239 ; Hasbullah, 2006: 37 ; Coleman, 2008: 415 ; Field, 2010: 100 ). Sehubungan dengan hal itu penguatan modal sosial budaya suatu masyarakat menjadi sangat penting. Sikap optimistis dan keniscayaan ini penting karena setiap masyarakat, termasuk dalam hal ini masyarakat di kawasan pesisir memiliki nilai-nilai positif yang perlu terus diperkuat kapasitasnya, seperti kerjasama, saling mempercayai, resiprositas, tolong-menolong, solidaritas sosial, dan kesadaran 
religious yang cukup tinggi. Kolaborasi antara masyarakat ekonomi, politik dan sipil menginvestasikan modal sosial dipengaruhi oleh berbagai faktor yang berkontribusi bagi terwujudnya kepentingan bersama maupun kepentingan bagi kelompok masyarakat tertentu dalam penguatan modal komunitas.

\section{KESIMPULAN}

\begin{tabular}{lrr}
\multicolumn{1}{c}{ Berpijak } & dari hal itu telah \\
diahsilkan & sebuah & model \\
pembeerdayaan & masyarakat & pesisir
\end{tabular} berbasis sosial budaya. Adapun bentuk penguatan modal komunitas yang dilakukan melalui proses sosialisasi, pendampingan dan pemberian bantuan modal finansial. Dalam menjaga keberlanjutan waisata bahari masyarakat mengembangkan pengawasan yang melibatkan masyarakat setempat, lembaga swadaya masyarakat, dan kelembagaan formal. Model promosi wisata bahari yang dikembangkan selama meliputi promosi melalui penyebaran brosur paket wisata bahari, promosi wisata bahari berbasis teknologi informasi, dan melalui kegiatan-kegiatan festival wisata bahari. Pengembangan wisata bahari di kawasan peisisr merupakan ruang hidup yang telah mempu meningkatkan kesejahteraan beberapa anggota masyrakat setempat .
Mencermati realitas pengembangan wisata bahari di kawasan pesisir di Bali sedang menghadapi berbagai tantangan baik dalam tataran arena, praksis, ranah, dan habitusnya, maka disarankan adanya upaya-upaya. Adapun upayauapaya yang dimaksud adalah sebagai berikut.

1. Pengembangan berbagai regulasi yang berbasis lokal dalam pengembangan wisata bahari.

2. Adanya pembinaan secara berkelanjutan kepada seluruh komponen masyarakat pesisir.

3. Adanya kajian dalam rangka penguatan keberadaan berbagai modal.

4. Adanya upaya pengiventarisan berbagai modal masyarakat untuk menemukenali modal yang bersifat produktif dan modal yang kontraproduktif. Kajian semacam ini akan berkontribusi terhadap peningkatan efektivitas investasi berbagai modal dalam pembangunan pada masyarakat setempat.

5. Diperlukan upaya merevitalisasi dan mereinterpretasi makna-makna berbagai modal guna memaksimalkan keberfungsian 
modal bagi kehidupan masyarakat dan lingkungan alam sekitannya. Hal ini perlu dilakukan karena modal sebagai suatu teks dikonstruksi dengan berbagai kepentingan dan ideologi, dan proses konstruksi selalu bermuatan kepentingan dan ideologi. Untuk itu, dalam merevitalisasi dan mereinterpretasi makna diperlukan penggunaan teori kritis.

\section{DAFTAR PUSTAKA}

Abdullah, Taufik, 1979, Tesis Weber dan Islam di Indonesia, dalam Taufik Abdullah (ed), Agama, Etos Kerja dan Perkembangan Ekonomi, Halaman 1 39,Jakarta: LP3ES.

Ardika, I Wayan. 2011.Gastronomi dalam Pariwisata Budaya dalam Pemberdayaan dan Hiperdemokrasi dalam Pembangunan Pariwisata. I Nyoman Darma Putra dan I Gde Pitana (Penyunting). Denpasar: Pustaka Larasan.

Anom, I Putu. 2010. Pembangunan Kepariwisataan Berkelanjutan. Dalam PariwisataBerkelanjutan dalam Pusaran Krisis Global. $\mathrm{Bu}$ Ciawi (Penyunting). Denpasar: Universitas Udayana.
Agger,Ben,2005, Teori Sosial Kritis, Yogyakarta: Kreasi Wacana.

Alatas, 1988,Mitos Pribumi Malas,Jakarta: LP3ES.

Andreski, Stanislav, 1989, Max Weber: Kapitalisme, Birokrasi dan Agama, Yogyakarta: Tiara wacana.

Asmawi, 1986, Sosialisasi Anak Nelayan Studi Tentang Pengasuhan Anak dan Pewarisan Budaya di Pulau Kodingareng, dalam Lontara, No. 31/86, Ujung Pandang : Universitas Hasanuddin.

Astika, Ketut Sudana, dkk., 1986, Peranan Banjar Pada Masyarakat Bali, Jakarta: Depdikbud.

1988, Sistem

Ekonomi Tradisional Sebagai Perwujudan Tanggapan Masyarakat Terhadap Lingkungannya, Denpasar: Depdikbud.

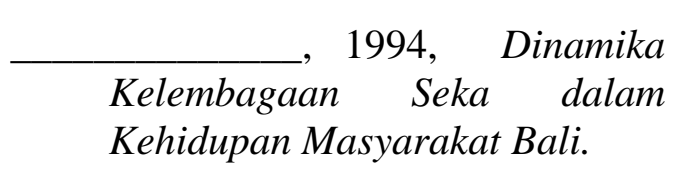

Ardika, I Wayan, Laut dan Orientasi Dalam Kebudayaan Bali, Makalah, Denpasar: Universitas Udayana.

Arif, Sritua, dan Adi Sasono, 1981,Indonesia: Ketergantungan dan Keterbelakangan, Jakarta: Lembaga Studi Pembangunan. 
Ketergantungan dan

Keterbelakangan, Jakarta: Sinar Harapan.

Atmadja, Nengah Bawa, 1988, Dana dan Bhakti Sebagai Konsep Manunggaling Kaula Gusti Dalam Perspektif Sejarah Bali, (Makalah), Singaraja: Universitas Panji Sakti. 1998, Komunitas Pantai Dalam Perspektif Sosiokultural, Makalah Seminar Nasional, Denpasar: Fakultas Sastra Universitas Udayana. 2006, Bali Pada Era Globalisasi, Singaraja: IKIP N Singaraja , 2006, Pemulihan Krisis Kebangsaan dan Multikulturalisme dalam Perspektif Kajian Budaya, makalah, Singaraja: Undiksha.

Badaruddin, 2005, Modal Sosial (Sosial Capital) dan Pemberdayaan Komunitas Nelayan, dalam Isu-isu Kelautan Dari Kemiskinan Hingga Bajak Laut, Yogyakarta: Pustaka Pelajar.

Bagus, I Gusti Ngurah, 1981, Ikhitisar Etnografi Bali Utara, (Sebuah Laporan Penelitian), Denpasar: Jurusan Antropologi, Faksas, Universitas Udayana.

Pergulatan Mencapai

Keunggulan, , Makalah Arahan dalam Seminar Kebaharian Nasdional, Denpasara : Universitas Udayana.

1999

Mengoptimalkan sasaran Potensi Kelautan Sebagai Isu Pasca Pemilu 1999, Makalah, Denpasar: Universitas Udayana.

Barker,Chris,2005, Cultural Studies, Teori dan Praktik, Yogyakarta: Bentang

Baudrillard, Jean,2000, Berahi, Yogyakarta: Bentang.

BaumGarther,M.P, 1994, Sosial Control From Bellow, dalam Donald Black (ed), Toward a General Theory of Sosial Control, Halaman 303-339, Orlando: Academic.

Beilharz, Peter,2002,Teori-teori Sosial, Yogyakarta: Pustaka Pelajar.

Bell, Daniel, 1984, Masyarakat PostIndustri Mendatang: Suatu Upaya Ke Arah Peramalan Sosial, dalam Margaret M. Poloma (ed), Sosiologi Kontenporer, Halaman 380402,Jakarta: Rajawali.

Bellamy, Richard, 1990, Teori Sosial Modern Perspektif Itali, Jakarta: LP3ES.

Blumer, Herbert, 1984, Interaksionis Simbolis Perspektif: Manusia dan Makna, dalam Margaret $\mathbf{M}$ Poloma (ed), Sosiologi 
Kontemporer,Halaman 259-282, Jakarta: Rajawali.

Boeke, J. H., D.H. Burger, 1973, Ekonomi Dualistis Dialog Antara Boeke dan Burger,Jakarta: Bhratara.

Boeke, J.H.,1983,Prakapitalisme Di Asia, Jakarta: Sinar Harapan.

Boelaars, Y, 1984, Kepribadian Indonesia Modern, Suatu Penelitian antropologi Budaya, Jakarta: Gramedia.

Brannen, Julia,1997,Memadu Metode Penelitian, Kualitatif \& Kuantitatif, Yogyakarta: Pustaka Pelajar.

Budiman, Arief,1996, Teori Pembangunan Dunia Ketiga, Jakarta: Gramedia.

Budiman, Hikmat, 1997, Pembunuhan Yang Selalu Gagal Modernisme dan Krisis Rasionalitas Menurut Daniel Bell,Yogyakarta: Pustaka Pelajar.

Campbell, Tom, 1994, Tujuh Teori Sosial, Sketsa, Penilaian, Perbandingan, Yogyakarta: Kanisius.

Capra, Fritjoe, 1997, Titik Balik Perdaban Sains Masyarakat dan Kebangkitan Kebudayaan, Yogyakarta: Yayasan Bentang Budaya.

Chambers, Robert, 1993, Pembangunan Desa Mulai Dari Belakang, Jakarta: LP3ES.
Chresty, F.T., J.R, 1987, Hak Penggunaan Wilayah pada Perikanan Laut: Definisi dan Kondisi, dalam Firial Marahudun dan Ian R. Smith (ed), Ekonomi Perikanan Dari Pengelolaan Ke Permasalahan Praktis, Halaman 141163,Jakarta: Yayasan Obor Indonesia.

Cristomy, $\mathrm{T}$ dan Untung Yuwono, 2004, Semiotika Budaya (ed), Jakarta: UI

Collier, William L, 1987, Budidaya Ikan dan Perikanan Rakyat, dalam Firial Marahudin dan Ian R. Smith (ed), Ekonomi Perikanan Dari Pengelolaan Ke Permasalahan Praktis, Halaman 281-307Jakarta: Yayasan Obor Indonesia.

Craib, Ian, 1984, Teori-Teori Sosial Modern Dari Parsons Sampai Habermas, Jakarta: Rajawali.

Crutchfield, James A., 1987, Implikasi Ekonomi dan Sosial dari Beberapa Alternatif Kebijaksanaan Utama untuk Pengawasan Penangkapan Ikan, dalam Firial Marahudin dan Ian R. Smith (ed), Ekonomi Perikanan Dari Pengelolaan ke Permasalahan Praktis, Halaman 3-25,Jakarta: Yayasan Obor Indonesia.

Dahrendorf, Ralf, 1984, Strukturalisme Konflik: Suatu Usul Bagi Penjelasan Struktur Sosial, dalam Margaret M. Poloma (ed), 
Sosiologi Kontemporer,Halaman

130-145, Jakarta: Rajawali.

Konflik dalam Masyarakat

Industri, Jakarta: Rajawali.

Danandjaja, James 1980, Kebudayaan

Petani Desa Trunyan di Bali,

Jakarta: Pustaka Jaya.

\section{Lampiran Model Pemberdayaan Masyarakat Pesisir dalam Pengembangan Wisata Bahari}

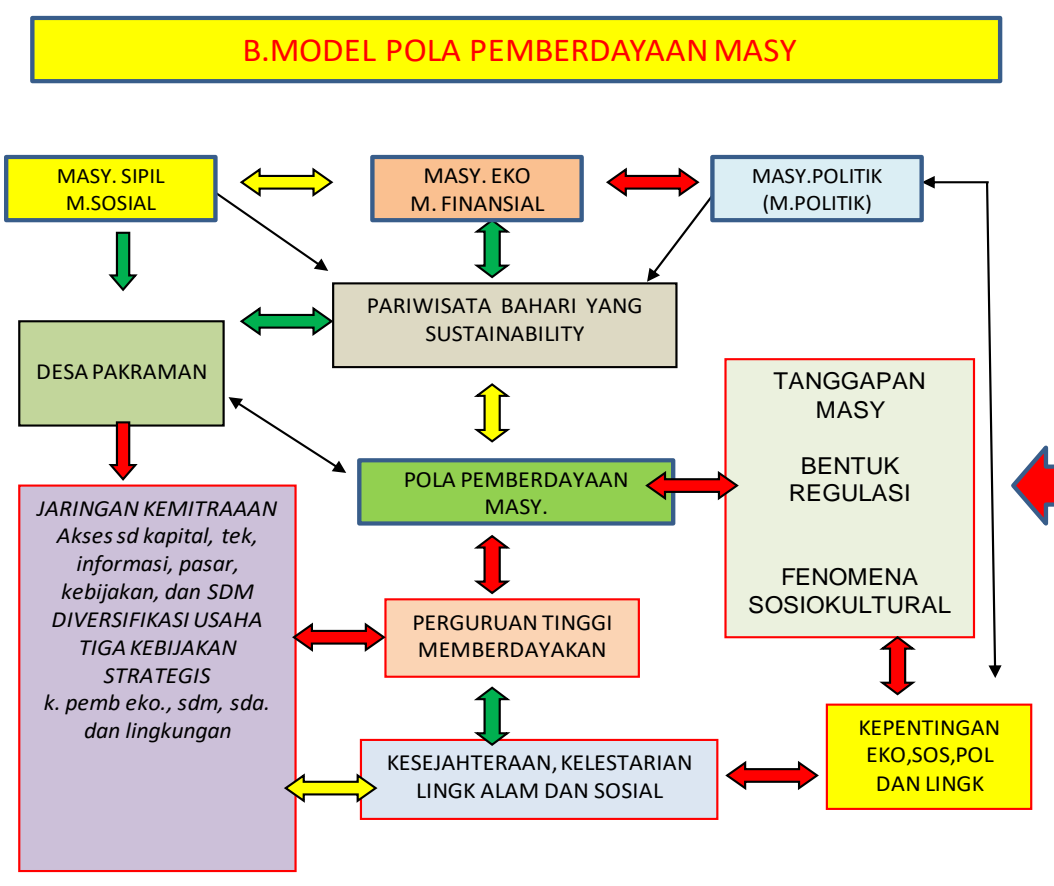

METODA

PENDEKATAN KUALITATIF

PENENTUAN INFORMAN

-INFORMAN PORPOSIVE

SNOWBALL

PENGUMPULAN DATA

-WAWANCARA,

-OBSERVASI,

-DOKUMEN DAN ANGKET

-FOKUS GROUF

DISKUSSION/FGD

ANALISIS DATA

TRIANGULASI

PRA

KAJIAN TEORI KRITIS;

(KRITIS, EMANSIPATORIS, DAN TRANSFORMATIF)

Dimodifikasi dari : Kusnadi, 2001; Mudana, 2009; 2012

HASIL: LAPORAN, ARTIKEL, MODEL 